\title{
Factors Influencing Survival in Patients with Pulmonary Hypertension: a Review from Single Pulmonary Hypertension Center Registry Baseline Data
}

\author{
VEIKSNIAI, İTAKOJANTYS SERGANČIŲJŲ PLAUTINE HIPERTENZIJA IŠGYVENAMUMĄ: \\ PLAUTINÉS HIPERTENZIJOS CENTRO REGISTRO PRADINIŲ DUOMENŲ APŽVALGA
}

\author{
GIEDRĖ GUREVIČIENE் ${ }^{1}$, DEIMANTĖ HOPPENOT ${ }^{1}$, EGLĖ EREMINIENÉ² ${ }^{2}$ SKAIDRIUS MILIAUSKAS ${ }^{1}$ \\ ${ }^{1}$ Department of Pulmonology, Hospital of Lithuanian University of Health Sciences Kauno klinikos, \\ ${ }^{2}$ Department of Cardiology, Hospital of Lithuanian University of Health Sciences Kauno klinikos
}

\begin{abstract}
Summary. Pulmonary hypertension $(\mathrm{PH})$ - is a severe progressive disease leading to the right heart failure. The survival of these patients ranges from several months to several years. The aim of the study: to investigate factors influencing PH patient survival. Matherial and methods. Data from the medical charts from the Hospital of Lithuanian University of Health Sciences Kauno klinikos (Kauno klinikos) PH center were retrospectively analyzed and 59 cases of adult patients diagnosed with PH confirmed by right heart catheterization during the period 2010-2017 were included into the study (18 men and 41 women). The statistical analysis was performed using Statistical Package for the Social Sciences (SPSS), version 20.0. P values of $<0.05$ were considered to indicate statistical significance. Results. Mean patient age was 59 years. Mean of overall survival of all cases was 50 months and was higher for patients with N-terminal B-type natriuretic peptide (NT-proBNP) $\leq 1,500 \mathrm{ng} / \mathrm{l}$, than for patients with NT-proBNP $>1,500 \mathrm{ng} / \mathrm{l}$. Risk of death was five times higher in patients with NT-proBNP>1,500 ng/l, comparing with the patients with NT-proBNP $\leq 1,500 \mathrm{ng} / \mathrm{l}$. The shortest survival was in PH associated with connective tissue disease group. The risk of death was lower in IPAH and Eisenmenger's syndrome group, comparing with PH associated with connective tissue disease (CTD). Worse survival was associated with right ventricular (RV) enlargement and severity of tricuspid regurgitation (TR) at the baseline. Conclusions. According to our data, PH associated with $C T D$, higher baseline NT-proBNP concentration and severe RV enlargement as well as greater TR are associated with worse survival and higher risk of death in $\mathrm{PH}$.
\end{abstract}

Key words: pulmonary hypertension, risk factors, survival.

Santrauka. Plautinè hipertenzija (PH) - sunki ir progresuojanti liga, sąlygojanti dešiniosios širdies nepakankamumą. Šia liga sergančiu pacientu išgyvenamumas paprastai svyruoja nuo keleriu mènesiu iki keleto metų. Tikslai. Nustatyti veiksnius, lemiančius sergančiuju PH išgyvenamumą. Tyrimo metodai. Retrospektyviai analizuoti Lietvos sveikatos mokslu universiteto ligonines Kauno Kliniku PH centro medicininiu dokumentu duomenys. I tyrima itraukti 59 suaugusieji, kuriems PH diagnoze patvirtinta atliekant dešiniosios širdies kateterizacija nuo 2010 iki 2017 metu (18 vyru ir 41 moteris). Statistiné analize atlikta naudojant Socialiniu mokslu statistini paketa (SPSS), 20.0 versiją. P reikšme $<0,05$ pasirinkta kaip statistiškai reikšminga. Rezultatai. Tiriamujų amžiaus vidurkis buvo 59 metai. Vidutinis išgyvenamumas sieké 50 mènesių ir buvo didesnis pacientams, kuriu aminoterminalinis pro-B tipo natriurezinis peptidas $(N T$-proBNP) $\leq 1500 \mathrm{ng} / \mathrm{l}$, palyginus su pacientais, kuriu NT-proBNP>1500 ng/l. PH pacientams, kuriu NT-proBNP koncentracija >1500 ng/l, stebèta penkis kartus didesne mirties rizika palyginus su pacientais, kuriu NT-proBNP koncentracija buvo $\leq 1500 \mathrm{ng} / \mathrm{l}$. Sergančiuju jungiamojo audinio ligu sąlygota PH išgyvenamumas buvo trumpiausias. Rizika numirti buvo mažesnè idiopatinès plaučiu arterijos hipertenzijos (IPAH) ir Eizenmengerio sindromo grupese, palyginus su PH, salygota jungiamojo audinio ligu. Blogesni PH pacientų išgyvenamumą lèmé dešiniojo skilvelio (DS) padidejimas ir didesnis triburio vožtuvo regurgitacijos laipsnis nustatyti ligos pradžioje. Apibendrinimas. Remiantis tyrimo duomenimis, jungiamojo audinio ligu sąlygota PH, didele pradinio NT-proBNP koncentracija kraujyje, ženkliai padidèjęs DS bei ryškus triburio vožtuvo nesandarumas nustatyti ligos pradžioje yra susiję su blogesniu sergančiujų PH išgyvenamumu bei didesne mirties rizika. Reikšminiai žodžiai: plautinè hipertenzija, rizikos veiksniai, išgyvenamumas. 


\section{Moksliniai darbai ir apžvalgos}

\section{INTRODUCTION}

Pulmonary hypertension $(\mathbf{P H})$ is a rare disorder that embraces a diversity of diseases with the increase in mean pulmonary arterial pressure (PAPm) $\geq 25 \mathrm{~mm} \mathrm{Hg}$ at rest, as assessed by right heart catheterization. Usually progressive pulmonary vascular remodelling and increased right ventricular afterload lead to right heart failure. Regardless of new medications and interventional therapy possibilities the survival of $\mathrm{PH}$ patients ranges from several months to several years $[1,2]$. The discussions about optimal $\mathrm{PH}$ treatment is still ongoing and choosing the right strategy for the right patient sometimes might be a complicated task despite of all new existing and available treatment options. It is believed that risk scores enable to personalise the risk of each patient thus optimisation as well as individualisation of therapeutic strategies can be reached. According to 2015 ESC/ERS $\mathrm{PH}$ guidelines regular assessment of multiple variables is recommended. While many studies and analysis investigating the survival and risk of death factors in $\mathrm{PH}$ patients have been performed in other countries this has never been done in Lithuania. The aim of this study was to investigate the possible factors (gender, age during $\mathrm{PH}$ diagnosis, etiology, baseline $\mathrm{N}$-terminal B-type natriuretic peptide (NT-proBNP) level, heart ultrasound data and six-minute walk test (6MWT)) affecting the mortality and survival of $\mathrm{PH}$ patients from $\mathrm{PH}$ center of Hospital of Lithuanian university of Health Sciences Kaunas Clinics.

\section{METHODS}

Data from the medical charts from the PH center of Hospital of Lithuanian University of Health Sciences Kauno klinikos (Kauno klinikos) were collected and retrospectively analyzed. The research protocol was approved by the Regional Biomedical Research Ethics Committee of the Lithuanian University of Health Sciences (Nr. BE-2-20). The study started Jan 2015 and finished Dec 2017.

\section{Study population}

59 cases of adult patients diagnosed with $\mathrm{PH}$ during the period 2010-2017 were included into the study (18 men and 41 women) of which 15 patients with idiopathic pulmonary artery hypertension (IPAH), 16 patients with $\mathrm{PH}$ associated with connective tissue disease (CTD), 10 patients with $\mathrm{PH}$ associated with Eisenmenger's syndrome and 18 patients with chronic thromboembolic pulmonary hypertension (CTEPH). All study patients were diagnosed with precapillary $\mathrm{PH}$ with mean pulmonary artery pressure $(\mathrm{PAPm}) \geq 25 \mathrm{~mm} \mathrm{Hg}$, pulmonary capillary wedge pressure $\leq 15 \mathrm{~mm} \mathrm{Hg}$ and pulmonary vascular resistance $\geq 3$ Wood units during right heart catheterization (RHC) test. In all cases, informed con- sent was obtained using a written consent form and was signed by the alive study individuals. The patients who died before the study were included into the data analysis with the permission of the Regional Biomedical Research Ethics Committee of the Lithuanian University of Health Sciences.

Influence of gender, age (years) during diagnosis, etiology, baseline NT-proBNP level (ng/l), baseline 6MWT result (meters), and baseline echocardiography data on survival (months) and mortality of $\mathrm{PH}$ patients were assessed. The time of RHC, that confirmed PH diagnosis, was considered to be the time of diagnosis. The results of NT-proBNP test, 6MWT and heart ultrasound that were performed in two months period before or after the diagnosis establishment were taken as the baseline.

\section{Statistical analysis}

The statistical analysis was performed using Statistical Package for the Social Sciences (SPSS), version 20.0. The normality assumption of data was verified with the Shapiro-Wilks test. The data that were distributed not normally were presented as median and ranges or interquartile range. Continuous variables were described as mean \pm SD or \pm SEM. For skewed distribution of the variables nonparametric tests were used. The Kaplan-Meier method with the log-rank test and Cox proportional hazards model were used to calculate survival rates, differences in survival curves and estimate the risk of death. Multivariable analysis for mortality was performed. $P$ values of $<0.05$ were considered to indicate statistical significance.

\section{RESULTS}

Mean overall survival of all selected $\mathrm{PH}$ patients was 50 months (95\% CI 40-59). 30 patients died (IPAH $\mathrm{n}=7$, CTD $\mathrm{n}=12, \mathrm{PH}$ associated with Eisenmenger's syndrome $n=2$, CTEPH $n=9$ ) during the seven-year period. The cause of death varied among the patients. The most common pathologies related with the death were progressive severe heart failure, thrombosis (stroke, infarction, pulmonary embolism), severe infections and sepsis (Table 1). The shorter survival was seen in $\mathrm{PH}$ associated with CTD group comparing with IPAH and Eisenmenger's syndrome group (31 months (95\% CI 18-44) vs. 56 months (95\% CI 41-71), $\mathrm{p}=0.028$ vs. 77 months (95\% CI 59-96), $\mathrm{p}=0.008$ accordingly) (Figure 1-B). The risk of death was found to be three times lower for patients with IPAH $(\mathrm{p}=0.039)$ and six times lower for patients with Eisenmenger's syndrome $(\mathrm{p}=0.017)$, comparing with $\mathrm{PH}$ associated with CTD. By the way mean survival between IPAH, CTEPH and Eisenmenger's syndrome patients did not differ.

In order to see if NT-proBNP has any prognostic implications, we divided patients into two groups: the 


\section{Moksliniai darbai ir apžvalgos}

Table 1. The cause of death of pulmonary hypertension patients from the Lithuanian University of Health Sciences Kauno klinikos PH center during 2010-2017

\begin{tabular}{|l|c|c|c|c|c|}
\hline Cause of death & $\begin{array}{l}\text { IPAH } \\
(\mathbf{n}=\mathbf{7})\end{array}$ & $\begin{array}{l}\text { CTEPH } \\
(\mathbf{n}=\mathbf{9})\end{array}$ & $\begin{array}{l}\text { Eisenmenger's } \\
\text { syndrome (n=2) }\end{array}$ & $\begin{array}{l}\text { CTD-PH } \\
(\mathbf{n}=\mathbf{1 2})\end{array}$ & $\begin{array}{l}\text { Total } \\
(\mathbf{n}=\mathbf{3 0})\end{array}$ \\
\hline Severe infection & 2 & 3 & 0 & 4 & 9 \\
\hline Progressive heart insufficiency & 4 & 1 & 2 & 1 & 8 \\
\hline Thrombosis & 0 & 1 & 0 & 4 & 5 \\
\hline Oncology & 0 & 1 & 0 & 2 & 3 \\
\hline Endartherectomy & 0 & 2 & 0 & 0 & 2 \\
\hline Unknown & 1 & 1 & 0 & 1 & 3 \\
\hline
\end{tabular}

Abbreviations: CTEPH - chronic thromboembolic pulmonary hypertension; CTD - PH - associated with connective tissue disease; IPAH - idiopathic pulmonary arterial hypertension.

Table 2. Demographic data of study patients.

\begin{tabular}{|c|c|c|c|c|c|}
\hline & $\begin{array}{l}\text { IPAH } \\
(n=15)\end{array}$ & $\begin{array}{l}\text { CTEPH } \\
(n=18)\end{array}$ & $\begin{array}{l}\text { Eisenmenger's } \\
\text { syndrome }(n=10)\end{array}$ & $\begin{array}{l}\text { CTD-PH } \\
(n=16)\end{array}$ & $\begin{array}{l}\text { Total } \\
(n=59)\end{array}$ \\
\hline Age (years), mean \pm SEM & $58 \pm 3$ & $65 \pm 3$ & $47 \pm 5$ & $59 \pm 3$ & $59 \pm 2$ \\
\hline Gender (male/female), n & $3 / 12$ & $7 / 11$ & $5 / 5$ & $3 / 13$ & $18 / 41$ \\
\hline Survival (months) mean \pm SEM & $56 \pm 8$ & $45 \pm 9$ & $77 \pm 9$ & $31 \pm 7$ & $50 \pm 5$ \\
\hline 6MWT (metres), median (range) & $312(30-540)$ & $315(90-470)$ & $240(50-406)$ & $208(70-510)$ & $289(30-540)$ \\
\hline NT-proBNP (ng/l), median (range) & $\begin{array}{c}1,473 \\
(127-6,963)\end{array}$ & $\begin{array}{c}4,206 \\
(763-28,191)\end{array}$ & $\begin{array}{c}948 \\
(58-5,616)\end{array}$ & $\begin{array}{c}2,384 \\
(315-16,912)\end{array}$ & $\begin{array}{c}1,783 \\
(58-28,191)\end{array}$ \\
\hline WHO functional class (I-II / III-IV), n & $6 / 9$ & $8 / 10$ & $4 / 6$ & $3 / 13$ & $21 / 38$ \\
\hline
\end{tabular}

Abbreviations: CTEPH - chronic thromboembolic pulmonary hypertension; CTD - PH - associated with connective tissue disease; IPAH - idiopathic pulmonary arterial hypertension; NT-proBNP - baseline N-terminal B-type natriuretic peptide concentration; SD - standard deviation; SEM - standard error of mean; WHO - baseline World Health Organization functional class; 6MWT - baseline 6 minute walk test.

group with NT-proBNP $\leq 1,500 \mathrm{ng} / \mathrm{l}$ and the group NT-proBNP $>1,500 \mathrm{ng} / \mathrm{l}$. Our data showed that mean survival was higher in group with NT-proBNP $\leq 1,500$ ng/l (70 months (95\% CI 60-80)) compared to group with NT-proBNP>1500 ng/l (38 months (95\% CI 24-51)) $(\mathrm{p}=0.002)$ (Figure 1-A). Risk of death was five times higher (95\% CI $\operatorname{Exp}$ (B) 1.6-14.4) in patients with NT-proBNP $>1,500 \mathrm{ng} / \mathrm{l}$, comparing with the patients with NT-proBNP $\leq 1,500 \mathrm{ng} / \mathrm{l}(\mathrm{p}=0.006)$.

When analysing echocardiographic data of our selected $\mathrm{PH}$ patients, only right ventricular (RV) enlargement and severity of tricuspid regurgitation (TR) were found as independent predictors of survival ( $p=0.001$ and $p=0.025$ accordingly). Surprisingly we did not found any correlation between the left ventricular ejection fraction $(\mathrm{p}=0.625)$, tricuspid annular plane systolic excursion (TAPSE) $(\mathrm{p}=0.114)$, pulmonary velocity acceleration time (PVAT) $(\mathrm{p}=0.377)$, pericardial effusion existence $(\mathrm{p}=0.557)$ and survival. However mean survival was higher in group of patients with $\mathrm{RV}<45 \mathrm{~mm}$ compare to the patient group with $\mathrm{RV}>45$ $\mathrm{mm}$ (62 months (95\% CI 50-74) vs. 26 months (95\% CI 20-32), $\mathrm{p}=0.001$ ) (Figure 1-C). Also we observed the higher survival of patients with $\mathrm{I}-\mathrm{II}^{\circ} \mathrm{TR}$ compared to the patients with III-IV ${ }^{\circ} \mathrm{TR}$ (56 months (95\% CI 46-74) vs. 36 months (95\% CI 26-46), p=0.025) (Figure 1-D).

Furthermore, the gender and the age at the diagnosis as well as baseline $6 \mathrm{MWT}$ result according to our data did not have any impact on $\mathrm{PH}$ patient survival. All demographic data are shown in detail in Table 2.

\section{DISCUSSION}

We presented the first baseline data evaluating the survival and the death risk predicting factors of Lithuanian $\mathrm{PH}$ patient population. As there still remain many discussions and disagreements on consensus of factors that predict mortality and prognosis in patients with $\mathrm{PH}$, we choosed to retrospectively analyse data from single university hospital $\mathrm{PH}$ center.

\section{Etiology}

Our study has shown that the only etiology - PH associated with CTD had importance to the PH patient survival. The data revealed shorter survival in $\mathrm{PH}$ associated with CTD patient group comparing with IPAH and Eisenmenger's syndrome groups. 


\section{Moksliniai darbai ir apžvalgos}
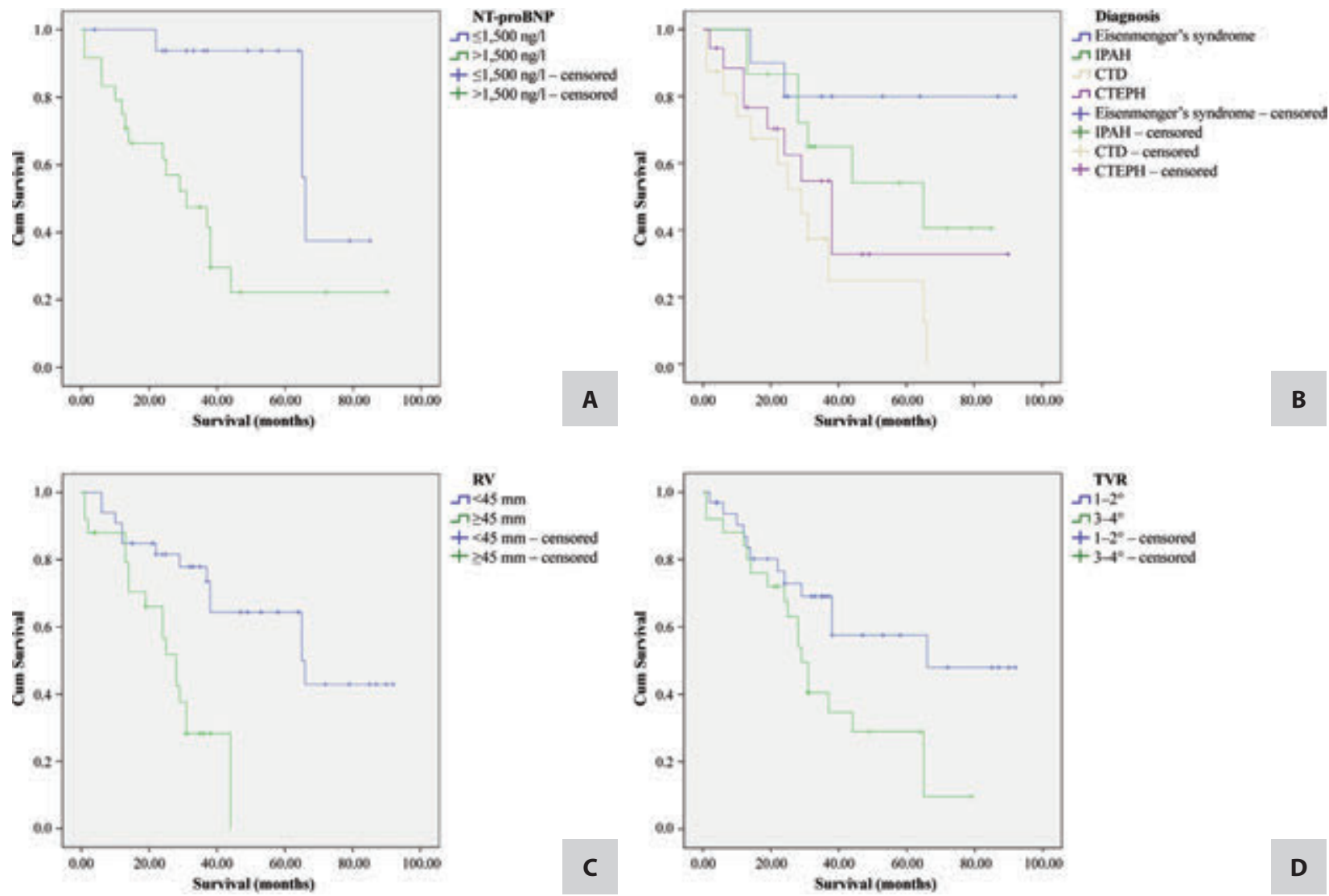

Figure 1. Survival curves according to NT-proBNP, pulmonary hypertension ethiology, RV size and TR: A - Kaplan Meier survival curve according to the serum NT-proBNP concentration. B-Kaplan Meier survival curve according to the pulmonary hypertension ethiology. C - Kaplan Meier survival curve according to the RV size. D - Kaplan Meier survival curve according to the TR.

Abbreviations: CTEPH - chronic thromboembolic pulmonary hypertension; CTD - pulmonary hypertension associated with conective tissue disease; IPAH - idiopathic pulmonary arterial hypertension; NT-proBNP - baseline N-terminal B-type natriuretic peptide concentration; RV - right ventricular; TR - tricuspid regurgitation.

Furthermore, the risk of death was lower for patients with IPAH and with Eisenmenger's syndrome, comparing with $\mathrm{PH}$ associated with CTD. Similar results were shown by the study where data from REVEAL registry were analyzed. They found that $\mathrm{PH}$ associated with CTD patients $(n=641 ; 68 \%$ systemic scleroderma $(\mathrm{SSc}))$, compared with IPAH patients $(\mathrm{n}=1251)$ had significantly worse one-year survival $(p<0.01)$ [3]. Meanwhile the data from REVEAL registry also suggested that despite the differences of hemodynamic values between cohorts of $\mathrm{PH}$ associated with Eisenmenger's syndrome, IPAH or heritable $\mathrm{PAH}, 4$ years survival was similar in all groups [4]. In another recent large study where 484 patients were enrolled, patients with PH associated with CTD $(n=114)$ also had higher risk of death compare to those with either IPAH $(n=272)$ or $\mathrm{PH}$ associated with other disease $(n=98)$ $(\mathrm{p}<0.001)$ [5]. Kunieda et al. found that CTEPH patients had better survival results than IPAH patients [6]. Diller et al. in meta-analysis, where 12 studies since 1971 to 2013 were included with total 1,131 patients showed that patients with $\mathrm{PH}$ associated with
Eisenmenger's syndrome did not have differences in survival when comparing total life span [7].

\section{NT-proBNP}

For $\mathrm{PH}$ patients usually the initial cause of death is right ventricular dysfunction and failure. NT-proBNP is known to be more stable molecule than the active brain natriuretic peptide (BNP) in vivo as well as in vitro [8] and it is proved that NT-proBNP concentration is related with right heart function [9]. Recently Fijalkowska et al. showed that serum NT-proBNP level of $\geq 1,400 \mathrm{ng} / \mathrm{l}$ correlates with poor long-term $\mathrm{PH}$ prognosis [10]. At about the same time Blyth et al. from University of Glasgow also published the data that serum NT-proBNP concentration $>1,685 \mathrm{ng} / \mathrm{l}$ suggests right ventricular systolic dysfunction in $\mathrm{PH}$ [11]. Likewise results got Gert-Jan Mauritz et al. showing that serum NT-proBNP concentration greater than $1,256 \mathrm{ng} / \mathrm{l}$ is associated with increased mortality. Furthermore, they stated that a decrease of NT-pro-BNP more than $15 \%$ per year was associated with survival [12]. Meanwhile Suntharalingama et al. showed that 


\section{Moksliniai darbai ir apžvalgos}

on patients with operable CTEPH NT-proBNP can be used in pre-operative evaluation for risk evaluation, either in post-operative period NT-proBNP correlates with disease progression as well as with the right ventricular function [13]. Our study results also showed that higher concentration of serum NT-proBNP (>1,500 ng/l) was strongly associated with lower $\mathrm{PH}$ patient survival and higher risk of death.

\section{MWT}

While the main characteristic of $\mathrm{PH}$ is exercise intolerance, measurement of exercise capacity takes great place in evaluation of $\mathrm{PH}$ patients. $6 \mathrm{MWT}$ is considered to be a relevant test for exercise capacity and a good indicator of patient ability to perform daily activities [14]. However, our study did not show any correlations between survival and 6MWT. Meanwhile the number of studies with greater quantity of cases showed the importance of $6 \mathrm{MWT}$ as an indicator of death risk in PH: Humbert et al. after multiple analysis of French registry confirmed, that reduced 6MWT demonstrates exercise limitation and is an excellent predictor of death in PAH [15]. Farber et al. analysed the data from REVEAL registry and showed that decreasing of $6 \mathrm{MWT}$ was strongly and significantly associated with decreased survival and poor prognosis, but by contraries improvement of 6MWT did not had any prognostic values [16]. According to the latest ESC/ERS guidelines, $6 \mathrm{MWT} \geq 440 \mathrm{~m}$ indicates low risk $(<5 \%)$ and better prognosis, whereas a $6 \mathrm{MWT}<165$ $\mathrm{m}$ indicates high risk $(>10 \%)$ and is associated with poor prognosis however 6MWT results should always be interpreted taking into account all the clinical context [17].

\section{Echocardiography}

The echocardiography is non - invasive test that provides information about anatomic abnormalities as well as hemodynamic values of right heart and pulmonary circulation that are important not just in $\mathrm{PH}$ diagnostic, but also in predicting survival and making therapeutic decisions [18]. In our study only, RV enlargement and severity of TR were revealed as independent predictors of mortality in patients with PH. Our study results might be limited by a small patient number and different test protocols. In series of studies the significance of echocardiography in predicting survival of $\mathrm{PH}$ patients was displayed. Jola Klosi et al. showed the relation between mortality and TAPSE $(\mathrm{p}=0.008)$, right ventricle ejection fraction $(\mathrm{p}=0.01)$ and pulmonary vascular acceleration time $(p=0.001)$ [19]. Several large studies revealed moderate or severe TR and the presence of pericardial effusion as independent predictors of mortality $[20,21]$.

\section{Who functional class, age and gender}

It is believed that the World Health Organization (WHO) functional class remains one of the most powerful predictors of survival at diagnosis as well as during follow-up. A worsening functional class proved to be one of the most alarming indicators of disease progression. Actually, our data showed only the tendency of WHO functional class being related with survival and risk of death however these data might be limited again by the small patient number included into the study. Our study results did not show any association between survival and age or gender. Very similar data were presented by NIH Registry. That was the first large-scale registry, where prognostic factors such as age and gender were not associated with survival in IPAH [18]. In Israel a national survey of IPAH data of 44 patients was performed. According to its data neither the age nor gender was associated with the survival [22]. A decade ago Miyamoto et al. presented data from the study were among the non-invasive variables of 43 patients with IPAH that were studied, age and gender also did not have any association with the $\mathrm{PH}$ patient survival [23].

Meanwhile the study where the data from REVEAL registry was used with 2716 cases included showed that men older than 60 years were independently associated with higher death risk (HR, 2.2; 95\% CI 1.6-3.0), comparing with the men younger than 60 years and also with the women group [24]. According to the data from Spain REHAP registry the univariate analysis showed that male sex and age were associated with higher risk of death and poor outcomes, however after multiple analyses only male sex remained as independent predictor of death [25]. In a retrospective study of single center in India, 61 cases with IPAH were analysed and younger age was found as predictor of poor prognosis and death. It should be noted that this population was younger than that included in the NIH Registry [21, 26].

The major limitation of our study was small study population. There are only less than three million people in Lithuania and two PH centers without overall registry. Our $\mathrm{PH}$ center performs all diagnostic procedures and offers professional follow-up as well as the treatment for half of Lithuania, so part of the patients suspected or diagnosed with $\mathrm{PH}$ might go to another center. Furthermore, patients that are suspected with $\mathrm{PH}$ but have multiple comorbidities or high age may never be sent to $\mathrm{PH}$ center from local hospitals. The second limitation - while only baseline data were analyzed, PH treatment was not taken into account. Probably because of these limitations the association between survival and factors, that were revealed as associated with survival and risk of death in other, larger 


\section{Moksliniai darbai ir apžvalgos}

cohort studies, were not found. Establishing of national or Baltic countries registry would provide better knowledge of this progressive and fatal disease. Further analysis of possible risk factors should be performed taking into account the treatment that was applied.

\section{CONCLUSION}

Our data suggests that the survival and risk of death of $\mathrm{PH}$ patients are associated with disease etiology, RV enlargement, TR severity and NT-proBNP level at the baseline. However, some independent predictors of mortality and survival were not identified probably because of the limitations of the study - small population and heterogeneity of some test technique. But there is no doubt, that risk stratification is crucial in patients with $\mathrm{PH}$ to guide further individual treatment decisions.

Gauta 20180316

Priimta 20180328

\section{REFERENCES}

1. Hoeper MM, Ghofrani HA, Grünig E, Klose H, Olschewski H, Rosenkranz S. Pulmonary hypertension. Dtsch Arztebl Int. 2017; 114(5):73-84.

2. Cannon JE, Su L, Kiely DG, Page K, Toshner M, Swietlik E, et al. Dynamic risk stratification of patient long-term outcome after pulmonary endarterectomy: results from the United Kingdom National Cohort. Circulation. 2016; 133(18):1761-71.

3. Chung L, Liu J, Parsons L, Hassoun PM, McGoon M, Badesch DB, et al. Characterization of connective tissue disease-associated pulmonary arterial hypertension from REVEAL: identifying systemic sclerosis as a unique phenotype. Chest. 2010; 138(6):1383-94.

4. Barst R, Dunbar I, Foreman AJ, McGoon MD, Rosenzweig EB. Four - and seven - year outcomes of patients with congenital heart disease associated pulmonary arterial hypertension (from the REVEAL Registry). Am J Cardiol. 2014; 113(1):147-55.

5. Kane GC, Maradit-Kremers H, Slusser JP, Scott CG, Frantz RP, McGoon MD. Integration of clinical and hemodynamic parameters in the prediction of long-term survival in patients with pulmonary arterial hypertension. Chest. 2011; 139(6):1285-93.

6. Kunieda T, Nakanishi N, Satoh T, Kyotani S, Okano Y, Nagaya N. Prognoses of primary pulmonary hypertension and chronic major vessel thromboembolic pulmonary hypertension determined from cumulative survival curves. Intern Med. 1999; 38(7):543-6.

7. Diller GP, Kempny A, Inuzuka R, Radke R, Wort SJ, Baumgartner $\mathbf{H}$, et al. Survival prospects of treatment naïve patients with Eisenmenger: a systematic review of the literature and report of own experience. Heart. 2014; 100(17):1366-72.

8. Downie PF, Talwar S, Squire IB, Davies JE, Barnett DB, $\mathrm{Ng}$ LL. Assessment of the stability of N-terminal pro-brain natriuretic peptide in vitro: implications for assessment of left ventricular dysfunction. Clin Sci (Lond). 1999; 97(3):255-8.

9. Noordegraaf AV, Westerhof N. Right ventricular ejection fraction and NT-proBNP are both indicators of wall stress in pulmonary hypertension. Eur Respir J. 2007; 29(4): 622-3.

10. Fijalkowska A, Kurzyna M, Torbicki A, Szewczyk G, Florczyk M, Pruszczyk P, et al. Serum N-terminal brain natriuretic peptide as a prognostic parameter in patients with pulmonary hypertension. Chest. 2006; 129(5):1313-21.
11. Blyth KG, Groenning BA, Mark PB, Martin TN, Foster JE, Steedman T, et al. NT-proBNP can be used to detect right ventricular systolic dysfunction in pulmonary hypertension. Eur Respir J. 2007; 29(4):737-44.

12. Mauritz GJ, Rizopoulos D, Groepenhoff H, Tiede H, Felix J, Eilers P, et al. Usefulness of serial N-terminal pro-B-type natriuretic peptide measurements for determining prognosis in patients with pulmonary arterial hypertension. Am J Cardiol. 2011; 108(11):1645-50.

13. Suntharalingam J, Goldsmith K, Toshner M, Doughty N, Sheares KK, Hughes R, et al. Role of NT-proBNP and 6MWD in chronic thromboembolic pulmonary hypertension. Respir Med. 2007; 101(11):2254-62.

14. Demir R, Küçükoğlu MS. Six-minute walk test in pulmonary arterial hypertension. Anatol J Cardiol. 2015; 15(1):249-54.

15. Humbert M, Sitbon O, Chaouat A, Bertocchi M, Habib G, Gressin V, et al. Survival in patients with idiopathic, familial, and anorexigen-associated pulmonary arterial hypertension in the modern management era. Circulation. 2010; 122(2):156-63.

16. Farber HW, Miller DP, McGoon MD, Frost AE, Benton WW, Benza RL. Predicting outcomes in pulmonary arterial hypertension based on the 6-minute walk distance. J Heart Lung Transplant. 2015; 34(3):362-8.

17. Galiè N, Humbert M, Vachiery JL, Gibbs S, Lang I, Torbicki A, et al. 2015 ESC/ERS Guidelines for the diagnosis and treatment of pulmonary hypertension: The Joint Task Force for the Diagnosis and Treatment of Pulmonary Hypertension of the European Society of Cardiology (ESC) and the European Respiratory Society (ERS): Endorsed by: Association for European Paediatric and Congenital Cardiology (AEPC), International Society for Heart and Lung Transplantation (ISHLT). Eur Heart J. 2016; 37(1):67-119.

18. McLaughlin VV, Presberg KW, Doyle RL, Abman SH, McCrory DC, Fortin T, et al. Prognosis of pulmonary arterial hypertension: ACCP evidence-based clinical practice guidelines. Chest. 2004; 126(1 Suppl):78S-92S.

19. Klosi J, Vevecka AH, Petrela E, Tase M. Clinical and biochemical predictive factors of mortality in patients with chronic with thromboembolic pulmonary hypertension. Webmed Central Pulmonary medicine. 2016; 7(5):WMC005110.

20. Raymond RJ, Hinderliter AL, Willis PW, Ralph D, Caldwell EJ, Williams W, et al. Echocardiographic predictors of adverse outcomes in primary pulmonary hypertension. J Am Coll Cardiol. 2002; 39(7):1214-9.

21. Grapsa J, Nunes MCP, Tan TC, Cabrita IZ, Coulter T, Smith BC, et al. Echocardiographic and hemodynamic predictors of survival in precapillary pulmonary hypertension seven-year follow-up. Circ Cardiovasc Imaging. 2015; 8(6):e002107.

22. Appelbaum L, Yigla M, Bendayan D, Reichart N, Fink G, Priel I, et al. Primary pulmonary hypertension in Israel. A national survey. Chest. 2001; 119(6):1801-6.

23. Miyamoto S, Nagaya N, Satoh T, Kyotani S, Sakamaki F, Fujita M, et al. Clinical correlates and prognostic significance of six-minute walk test in patients with primary pulmonary hypertension. Comparison with cardiopulmonary exercise testing. Am J Respir Crit Care Med. 2000; 161(2 Pt 1):487-92.

24. Benza RL, Miller DP, Gomberg-Maitland D, Frantz RP, Foreman AJ, Coffey CS, et al. Predicting survival in pulmonary arterial hypertension. Insights from the registry to evaluate early and long-term pulmonary arterial hypertension disease management (REVEAL). Circulation. 2010; 122(2):164-72.

25. Escribano-Subias $P$, Blanco I, López-Meseguer M, LopezGuarch CJ, Roman A, Morales P, et al. Survival in pulmonary hypertension in Spain: insights from the Spanish registry. Eur Respir J. 2012; 40(3):596-603.

26. Rajasekhar D, Balakrishnan KG, Venkitachalam CG, Tharakan JA, Titus T, Subramanian R, et al. Primary pulmonary hypertension: natural history and prognostic factors. Indian Heart J. 1994; 46(3):165-70. 